\title{
An Assessment of Woody Plant Water Source Studies from across the Globe: What Do We Know after 30 Years of Research and Where Do We Go from Here?
}

\author{
Md. Shawkat I. Sohel ${ }^{1,2, *}$, Mohammed Abdus Salam ${ }^{3}$ and John Herbohn ${ }^{1,4}$ \\ 1 Tropical Forests and People Research Centre, University of the Sunshine Coast, Maroochydore, \\ Queensland 4556, Australia; jherbohn@usc.edu.au \\ 2 Ecology, Forestry and Biodiversity Division, Center for Environmental and Geographic Information Services, \\ Dhaka-1212, Bangladesh \\ 3 Department of Environmental Science and Disaster Management, Faculty of Science, Noakhali Science and \\ Technology University, Sonapur 3814, Bangladesh; s_salam1978@yahoo.com \\ 4 Tropical Forestry Group, School of Agriculture and Food Sciences, The University of Queensland, \\ St. Lucia, Queensland 4072, Australia \\ * Correspondence: sohel_for@yahoo.com; Tel./Fax: +8801751967676
}

Received: 10 March 2019; Accepted: 25 April 2019; Published: 21 May 2019

check for updates

\begin{abstract}
In the face of global climate change, water availability and its impact on forest productivity is becoming an increasingly important issue. It is therefore necessary to evaluate the advancement of research in this field and to set new research priorities. A systematic literature review was performed to evaluate the spatiotemporal dynamics of global research on woody plant water sources and to determine a future research agenda. Most of the reviewed studies were from the United States, followed by China and Australia. The research indicates that there is a clear variation in woody plant water sources in forests due to season, climate, leaf phenology, and method of measurement. Much of the research focus has been on identifying plant water sources using a single isotope approach. Much less focus has been given to the nexus between water source and tree size, tree growth, drought, water use efficiency, agroforestry systems, groundwater interactions, and many other topics. Therefore, a new set of research priorities has been proposed that will address these gaps under different vegetation and climate conditions. Once these issues are resolved, the research can inform forest process studies in new ways.
\end{abstract}

Keywords: dual isotope; forest management; soil water; stable isotopes; xylem water

\section{Introduction}

The dynamics of soil water availability and water use by plants are important for any ecosystem functions, including ecosystem resilience to a changing climate [1,2]. Water availability to plants in dry habitats is a matter of concern because plant productivity is often limited by soil moisture [3,4]. How this plant-water interaction responds to climate change, such as warming and droughts, has been a recent source of debate [5,6]. Observations suggest that global mean temperatures are set to rise by 0.3 to $4.8^{\circ} \mathrm{C}$ by the late-21st century [7]. Hence, there is a high probability of increasing water stress in some regions of the world. Forest productivity and vulnerability to climate change are critically dependent upon how plants cope with water stress in warmer and drier climates [8]. Species diversity, ecosystem structure, and forest composition are also highly influenced by water availability $[9,10]$.

To understand complex plant-water interactions, isotopic compositions $(\delta 2 \mathrm{H}$ and $\delta 18 \mathrm{O})$ of different water pools (e.g., soil water, stream water, rain water, and groundwater) are compared with plant water isotope compositions [11-14]. This is because, in general, there is no isotopic 
fractionation occurring during water uptake by plants [11], although mangrove plants are a notable exception [15]. Hence, identification of the isotopic composition of stem water can determine potential plant water sources $[11,16]$. This technique has been widely used in determining water sources used by plants [17-22].

In dry environments where water is limited, some plants have deep roots and uptake water from deep soil or groundwater sources [23]. By doing so, deep roots may also contribute to the distribution of water in the upper soil layer through hydraulic lift [24]. This water uptake strategy can support plants that are dependent on water in the upper soil layer. Some plants also use different water sources during different seasons $[23,25]$, thereby reducing competition for water and increasing the survival rate of plants during periods of water shortage [25].

Research into tree water sources is of a trans-disciplinary scope and importance, and is commonly undertaken by ecologists, geographers, agriculturalists, foresters, and hydrologists. As scientific development and environmental pressures, such as global climate change, increase, it is increasingly necessary to evaluate recent research progress, and to challenge current research priorities. An evaluation of the research into tree species' water sources and use strategies, with special consideration given to the water resource scarcity, can provide valuable information for mitigating the potential future impacts of global climate change on efficient water use, associated forest productivity, and ecosystem functioning. From this perspective, it is time to evaluate the current state of global research into these topics. To do this, a systematic review of the scientific literature was undertaken and provides an update on its current relevance. This detailed review will help to increase our understanding of current trends in woody plant water sources research and identify relevant research gaps. The specific objectives are to:

(1) Evaluate the spatiotemporal dynamics of global research on woody species water sources; and

(2) Set new research priorities in the study of woody species water sources.

\section{Materials and Methods}

\subsection{Literature Search and Article Inclusion Criteria}

To identify the water sources of woody plants, a systematic literature search was undertaken using the ISI Web of Science, covering the period from 1970 to 2014.The following search command with relevant key words was used:

Literature search command $=\left(\right.$ forest ${ }^{*}$ OR tree* OR plant ${ }^{*}$ OR "riparian tree" OR "stream side tree" OR planted* OR reforest* OR afforest* OR "mixed plantation" OR "mixed forest" OR "native forest" OR agroforest* OR "agro forest") AND ("water source" OR "water use") AND ("soil water" OR "stream water" OR "rain water" OR "ground water" OR stream* OR "soil water partition" OR "ecohydrologic separation") AND (isotope* OR "stable isotope" OR "dual isotope")

The search initially yielded 613 articles. All 613 retrieved articles were then reviewed based on their title, abstract, and main text to evaluate their suitability for inclusion in the final analysis. Studies that met the following criteria were included:

- The research was undertaken in forest areas;

- The research focused on woody species (trees and shrubs) only;

- The water source was measured without any treatment, such as measuring isotopes before and after pruning or harvesting;

- The article was written in English; and

- The article had a clear description of the investigated species.

These selection criteria resulted in 99 articles being included in the literature review (See Figure 1 and Supplementary Table S1). 
ISI web of science

Literature search command $=\left(\right.$ forest ${ }^{*}$ OR tree* OR plant ${ }^{*}$ OR "riparian tree" OR "stream side tree" OR planted* OR reforest* OR afforest* OR "mixed plantation" OR "mixed forest" OR "native forest" OR agro forest* OR "agro forest") AND ("water source" OR "water use") AND ("soil water" OR "stream water" OR "rain water" OR "ground water" OR stream* OR "soil water partition" OR "Eco hydrologic separation") AND (isotope* OR "stable isotope" OR "dual isotope").

Time period: January 1, 1970 to December 30, 2014

Document type: Article/peer reviewed journals

Language considered: English

Total articles yielded: 613

Excluded article (Zoology, library science, urban studies, anthropology, astronomy, fisheries, government law, imaging science, nuclear science, remote sensing, marine freshwater biology, infectious diseases, social science, history): $\mathbf{5 9}$

Total article yielded: 554

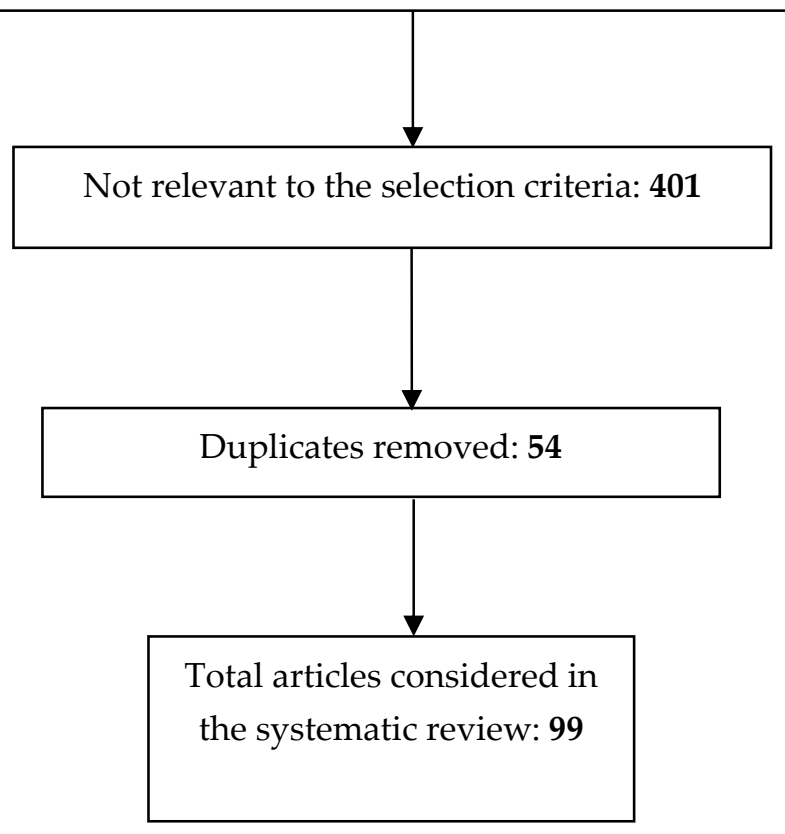

Figure 1. Overview of the article inclusion and screening process.

\subsection{Data Extraction, Interpretation, and Analysis}

To understand the research publication trends among the included articles, the number of papers published per year between 1970 and 2014 was calculated. To identify the woody plant water sources, information on the possible water sources, such as rain, stream, fog, rock, soil, and groundwater, were extracted. In the case of soil water, data on the depth the woody plants were sourcing the water from were also extracted. Since the data on soil water depth reported in the different publications followed different standards (some are reported in meters $(\mathrm{m})$ ), while others are reported in centimeters $(\mathrm{cm})$, the data were converted into a single unit. To identify the variation in woody plant water sources due to climate and leaf phenology, information on the study area's climatic conditions and species' leaf phenology (i.e., evergreen, deciduous, semi-evergreen, and semi-deciduous) were extracted. The 
research focus was identified from the article title and abstract. For mapping the spatial distribution of the included studies, ArcGIS 10.3.1 was used. All the extracted information was graphically represented using Sigma Plot (v14, San Jose, CA, USA).

\section{Results}

\subsection{Publication Trends and Geographical Distribution of Research on Woody Plant Water Source}

The systematic review considers 99 peer-reviewed articles from 43 journals (see Supplementary Table S1). More than half of the publications identified (73\%) were published in two journals (i.e., Oecologia, $n=21$; Plant and Soil, $n=10$ ). Figure 2 indicates that Oecologia is the highest cited journal in tree water source research. With 1359 citations, Oecologia's central position in Figure 2, and its connection with all the other journals, suggests that it has substantial influence in tree water source research. The second most influential journal is Plant and Soil with 437 citations.

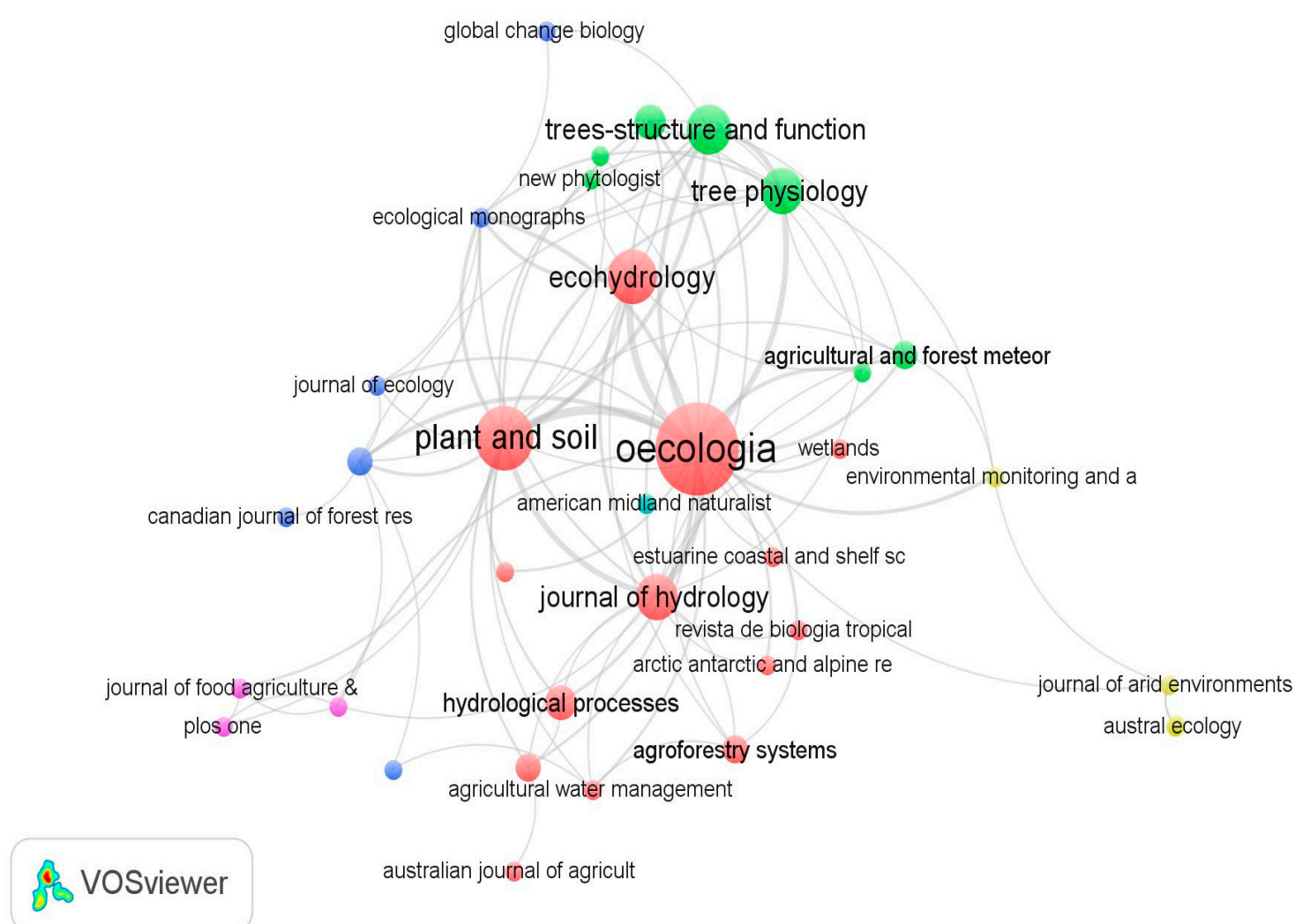

Figure 2. The research journals that the reviewed articles were published in. Note: The size of the nodes/circles indicates the number of articles from each journal. The lines indicate citation connections between journals. Similar colors indicate a single cluster and journals that are highly related are positioned close to each other.

The reviewed articles included research from 18 countries. Most of the studies were from the United States $(n=33)$, followed by China $(n=20)$, and Australia $(n=16)$, with various other countries having between one and four studies only (Figure 3a). When considering the climatic region of focus, most studies were undertaken in semi-arid regions (32\%), followed by tropical (16\%), arid (15\%), and Mediterranean (14\%) regions (Figure $3 \mathrm{~b}$ ). The annual proportion of the published articles increased significantly with the year for both developed and developing countries (Figure 3c). It is important to note that, based on the search criteria, no relevant studies were published before 1991. 


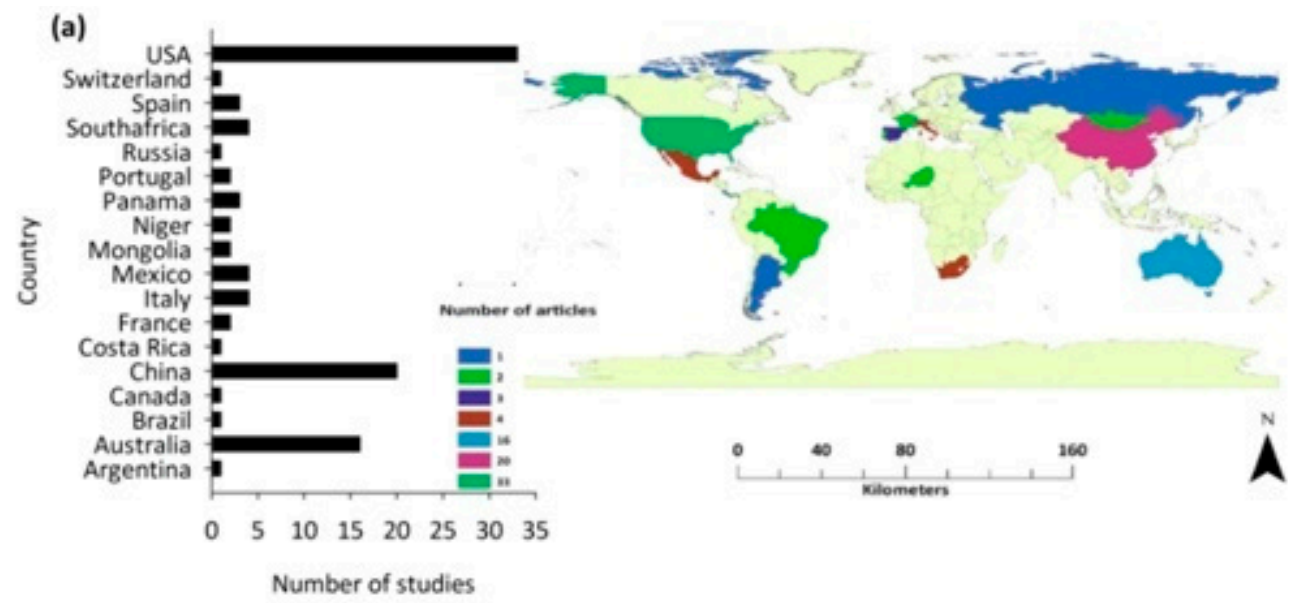

(b)
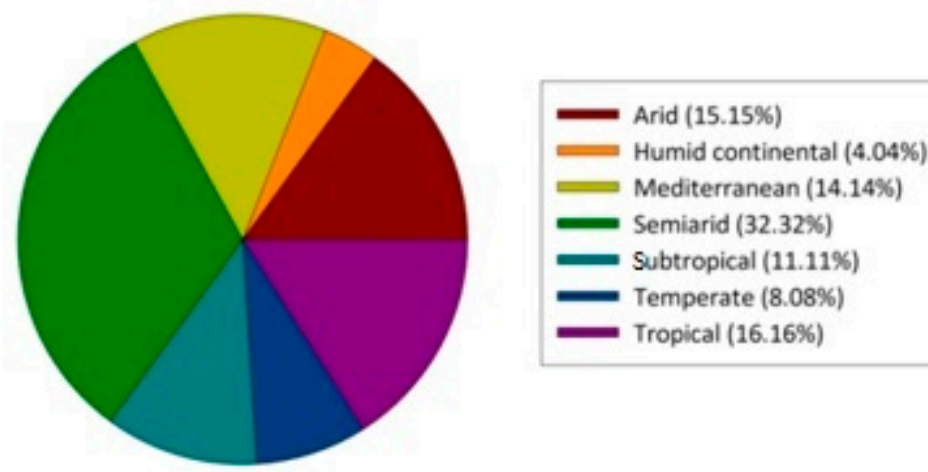

(c)

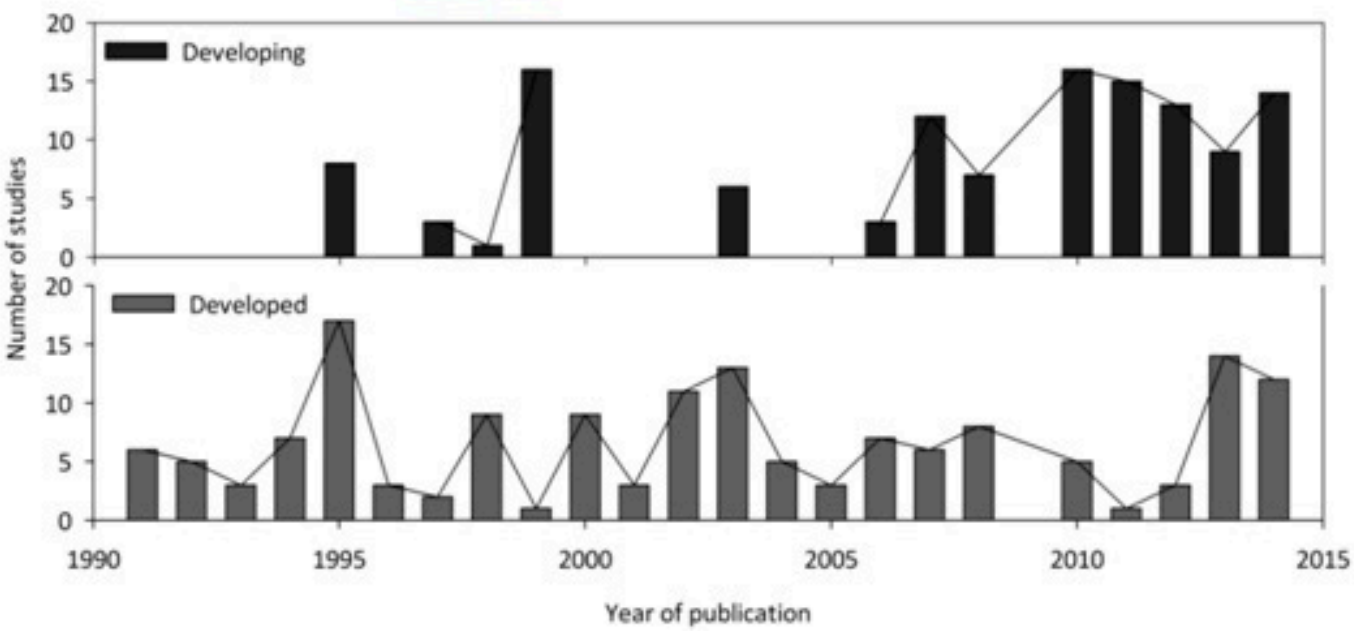

Figure 3. (a) The map and bar graph indicate the global distribution of publications on woody plant water source $(\mathbf{b})$ The pie chart represents the proportion of publications on woody plant water source across different climatic regions (c) The publication trend (between 1970 and 2014) for research articles related to woody plant water source in forest areas in developed and developing countries (based on the United Nations World Economic Situations and Prospects classification).

\subsection{Research Focus on Woody Plant Species}

Figure 4 displays the research focus of the reviewed articles by mapping the terms most frequently cited in the abstracts. The term "use" (i.e., tree water use) was most frequently cited in the abstracts. Related terms, such as "drought", "summer", "transpiration", "soil water partitioning", and "precipitation", were also frequently cited. Over recent years, the terms "drought", "rainfall", "deep soil water", and "growth" have been increasingly cited in research article abstracts. The reason for the use of these terms relates to increasing impacts of climate change. 


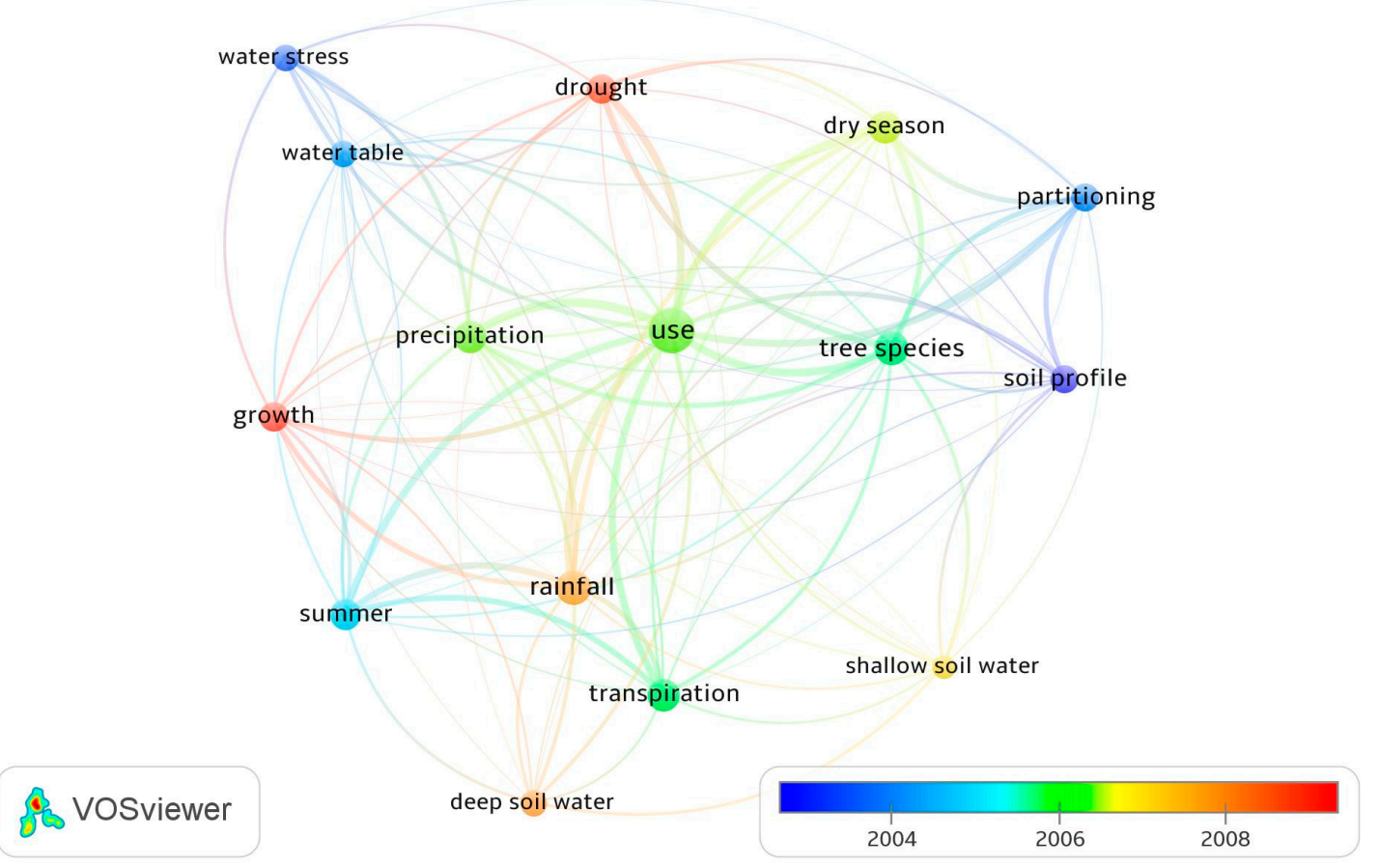

Figure 4. The terms most frequently cited in the abstracts of reviewed articles. Note: Each term was cited at least 10 times; Colors are based on the years for which the terms were most frequently cited; the distance between two nodes indicates the degree of relatedness between the terms.
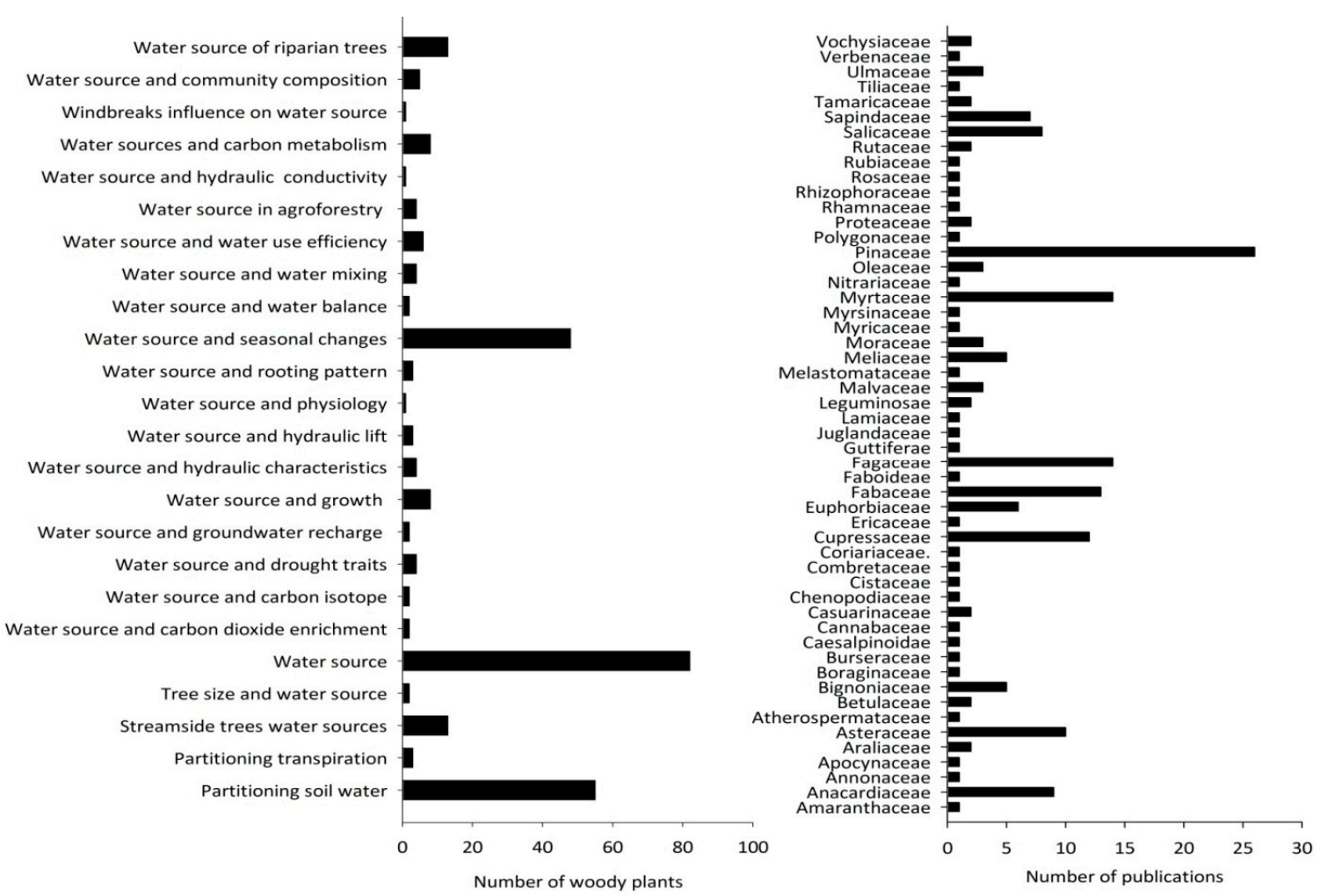

Figure 5. The right side bar graph represents the distribution of research focus among woody plant families (note: each publication may have more than one family). The left side bar graph indicates the research focus on woody plant water source. 
Application of stable hydrogen and oxygen isotopes in the woody plant water source studies was mostly focused on identifying sources and uses of water. Among the 276 woody plant individuals investigated (from 193 species), the research focus for 83 of them was on their water sources, such as soil, groundwater, and stream water. Other key topics of research focus were partitioning of soil water sources $(n=55)$ and seasonal changes in water sources $(n=48)$. Much less focus was given to the nexus between water source and tree size, growth, transpiration partitioning, drought, water use efficiency, agroforestry systems, groundwater interactions, and many other topics (Figure 5). The research focus was not evenly distributed among plant families. The studied woody plant species $(n=193)$ belonged to 53 families (Figure 5). Most of the studies were focused on the Pinaceae family $(n=26)$, followed by Myrtaceae and Fagaceae $(n=14)$, and Fabaceae $(n=13)$. All other families were represented in much fewer studies.

\subsection{Woody Plant Water Sources and Their Variation due to Season, Climate, Leaf Phenology, and Method of Measurement}

To investigate woody plant water source variation, data were obtained from 109 deciduous, 155 evergreen, 1 semi-evergreen, and 11 semi-deciduous woody plants. Leaf phenology has a great influence on plant water use strategies. The evergreen and deciduous woody plants mostly used soil water and groundwater (Figure 6a). There was climatic variation observed in the plant's water sources. Groundwater as a source of water was more common in dry climates, such as in arid and semi-arid regions. Most of the plants in tropical regions sourced water from the soil (Figure $6 \mathrm{~b}$ ), and there was a clear seasonal variation observed in soil water uptake depth. The data shows that, in the dry season, most of the woody plants uptake water from the $<100 \mathrm{~cm}$ soil layer. Water uptake from the deep soil layer $(>100 \mathrm{~cm}$ ) is found to be greatest during the wet season (Figure $6 \mathrm{c}$ ).
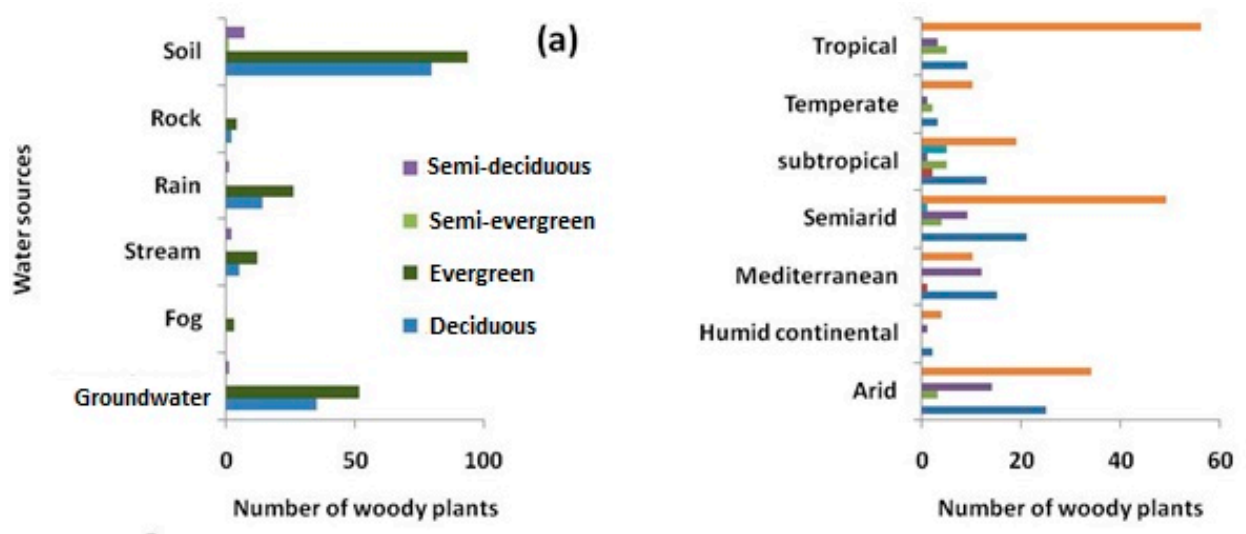

\section{(b)}
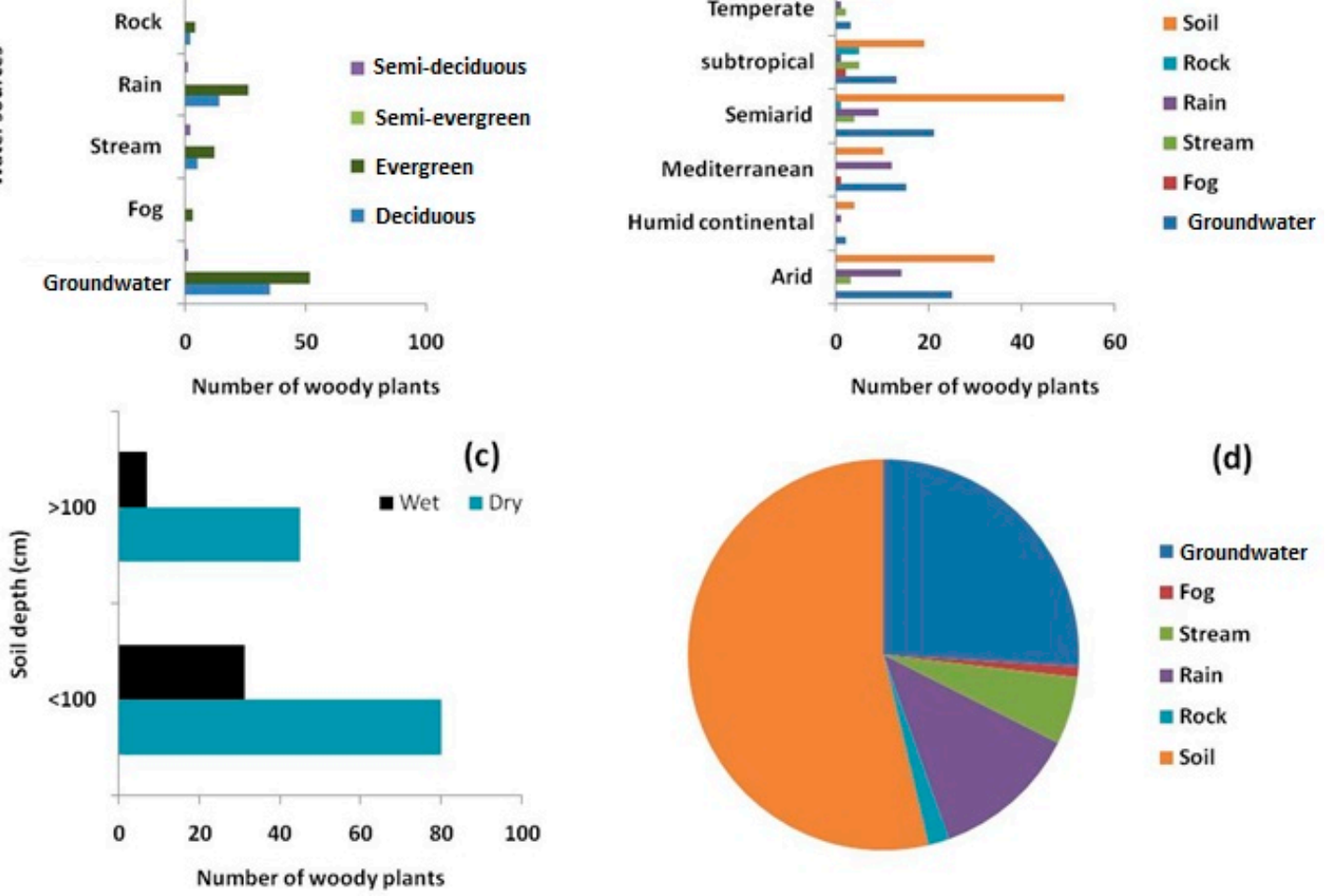

Figure 6. (a) Woody plant water source variation in relation to leaf phenology; (b) Climatic variation of plant water sources; (c) Seasonal variation in water uptake from different soil depths; (d) Proportion of water sources of woody species. 
The literature reveals that plant uptake of water is from diverse sources, i.e., soil water, groundwater, rainwater, stream water, and other sources. Among the 276 trees (from 193 species) from different geographic locations, $54 \%$ obtained water from soil, followed by groundwater $(26 \%)$, rainwater $(12 \%)$, and stream water $(6.75 \%)$ (Figure $6 \mathrm{~d}$ ). To identify plant water sources, the stable Hydrogen and Oxygen isotope analysis approach was widely used. The review shows that the single isotope approach was most commonly used to detect plant water source. With this approach, soil water and groundwater were found to be the major sources of water. Among the 276 woody plants studied, 115 were investigated through the dual isotope approach and 161 were investigated through the single isotope approach (Figure 7a). Plant water sources were identified through the cryogenic vacuum distillation method for 215 of the 276 studied woody plants (Figure 7b).

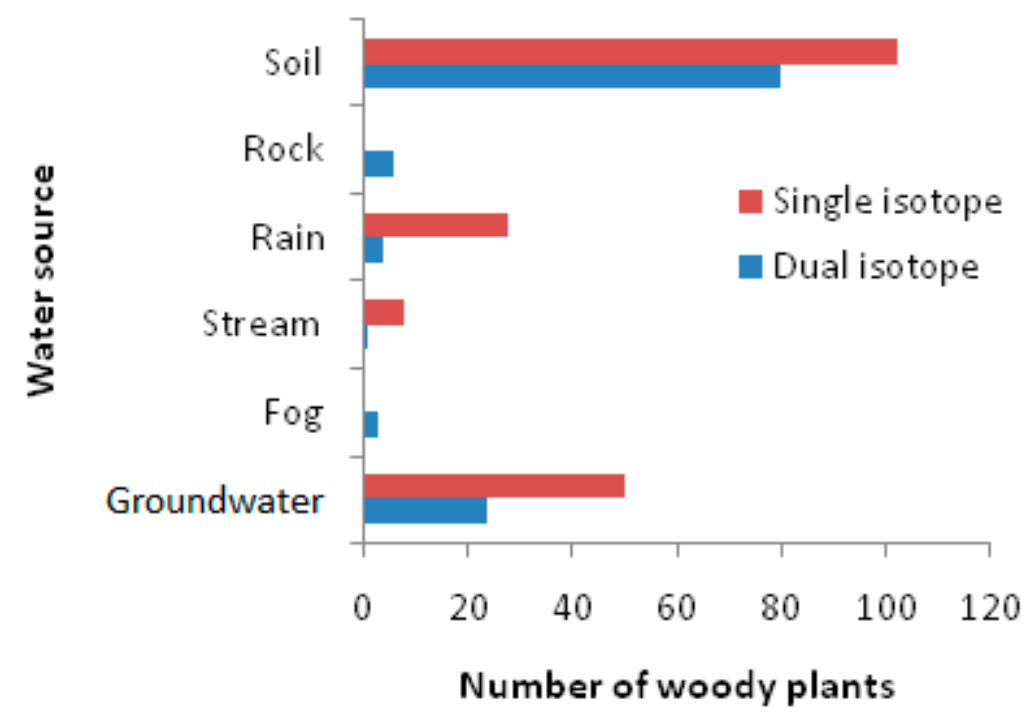

(a)

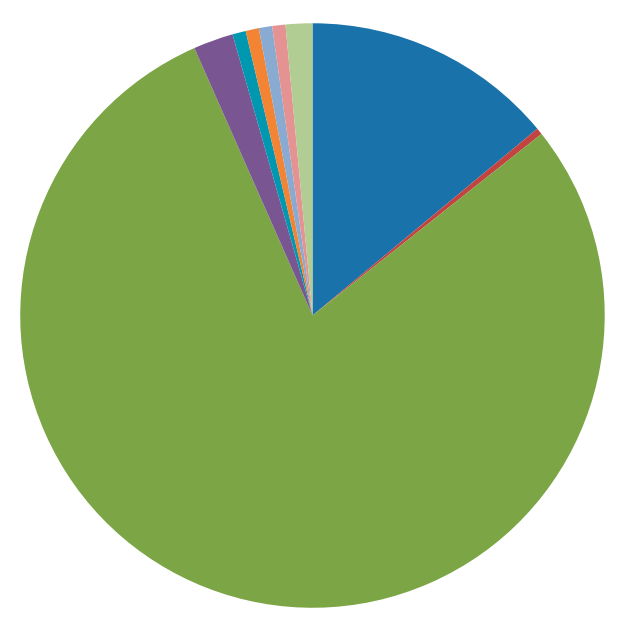

\author{
Azeotropic distillation \\ - Cellulose synthesis and isotope \\ - Cryogenically distillation \\ Dendrocronological method and \\ oxygen isotope cellulose analysis \\ - Direct equilibration \\ n Liquid-vapour equilibration \\ - Pressure chamber and suction \\ sysimeter \\ - Vacuum distillation
}

(b)

Figure 7. (a) Water source variation due to changes in isotopic approach; (b) Method used for plant water source determination. 


\section{Discussion}

\subsection{Geographic Biases in Woody Species Water Source Research}

This systematic literature review shows that the research on plant water sources is geographically biased. Most research has been undertaken in the United States, followed by China and Australia. Many components, such as research history, research capability, interests of individuals and organizations, and priorities of funding agencies and governments, have influenced the type of research conducted and published [26]. The geographic distribution of the research has also been influenced by the research capacity and level of support for research within particular countries and regions.

\subsection{Environmental Significance and Factors Influencing Plant Water Sources Study}

Plant water sources vary greatly with geographic location, climate, season, and the type of plant (Figure 2, Figure 4, and Figure 5). Understanding how plants partition water sources has wide application in managing ecosystems. This knowledge is increasingly applied by ecologists and hydrologists. Research has found that some trees (e.g., Quercus gambelii) do not use summer rainfall, while some species (e.g., Juniperusos teosperma) do [27]. Studies have also found other plant water use strategies, including that streamside trees do not always utilize stream water [28], smaller sized tropical trees uptake more deep soil water than large sized tropical trees [29], some trees use fog water [30], and some species seasonally shift their water sources [31,32]. Such strategies provide plants with the ability to adapt to competitive and extreme environments, which in turn influences the distribution and diversity of species in an ecosystem [33,34]. Opportunistic use of different plant water sources and strategies improves complementarity among different tree species. Knowledge of these complementary relationships can help guide the design and management of mixed-species plantations, including multiple-use agroforestry systems [35].

\subsection{Research Gaps and New Research Priorities}

\subsubsection{The Need for High-Frequency Sampling and Dual Isotope Approaches}

The water sources of only a small number of woody plant species have been investigated to date. High-frequency sampling of soil and xylem waters across a diverse climate and vegetation types is needed. Furthermore, it will be useful to inform forest process studies of new ways and generate a new set of research priorities and questions. Many studies in different eco regions have used the single isotope approach (i.e., using $\delta^{2} \mathrm{H}$ or $\delta^{18} \mathrm{O}$ ) to measure tree water sources (see Supplementary Table S1). Some recent examples include Goujun et al. [36] and Engel et al. [37]. However, very few studies have used the dual isotope approach for quantifying plant water sources (see Supplementary Table S1). The power of using the dual isotope approach is that, compared to the single isotope approach, there is a better chance of determining if water samples in the environment or in the plant were influenced by post-precipitation evaporation effects.

\subsubsection{Do Species with High Mortality Rates Source Their Water Mainly from Surface Layers?}

Vegetation in water-limited ecosystems depends largely on access to deep water sources to withstand dry periods [38]. Understanding the patterns of, or differences in, the use of water sources under dry conditions is therefore necessary to properly observe the responses of forest trees in seasonally dry ecosystems. By identifying trees with high mortality rates and determining whether these species primarily source their water from the surface layers of the soil profile, or whether they are capable of taking up water from deeper sources (e.g., deep soil water or groundwater) during dry conditions may help us to understand one of the causes of tree mortality. A recent study by shows that, in extreme dry conditions, the contribution of deep water sources declines, which results in widespread tree mortality and crown defoliation [38]. A review by Anderegg et al. [39] also indicates that tree mortality is triggered by drought and temperature stress. Hence, a detailed knowledge of plant water 
sourcing strategies may help us understand one potential mechanism underlying tree mortality and niche differentiation, thus improving predictions of future forest decline or community shifts with changing patterns of water availability.

\subsubsection{During Droughts, Do Large and Small-Sized Trees Source Their Water from the Same or} Different Soil Depths?

Many regions of the world face increasing drought conditions, which can alter forest structure and function [40]. A recent study by concludes that, during drought, large trees suffer most in forests across the globe [41]. However, there are other studies showing that small-sized trees are more prone to mortality than large-sized trees [42-45]. In general, compared to small trees, larger trees have greater access to deep soil water during drought because of their deeper root systems [46]. This means that large trees are less susceptible to decline or mortality during drought. However, there are some exceptions to this rule because some large-sized trees lack a deep root system [47,48]. Therefore, investigating the depths that large and small-sized trees uptake water from during drought or dry conditions will improve our understanding of the water use strategies of different-sized trees.

4.3.4. What Is the Relationship between Growth and the Depth at Which Species/Individuals Uptake Water?

The relationship between access to soil water and rainforest tree productivity is an interesting issue in the field of Eco hydrology. In forests where access to light is not a major limitation to productivity, exploring underground resource competition, such as competition for water, could help to answer the question of why the growth rates of some trees are higher than other trees of the same age. However, research into this topic has produced mixed results. For example, Romero-Saltos et al. [49] found that large-diameter trees uptake water from deep in the soil profile. In contrast, Meinzer et al. [50] discovered that, during dry periods, small-diameter trees withdraw more water from deep soil layers than large-diameter trees. Therefore, using long-term datasets to identify trees with high growth rates, and then investigating the soil depths from which those trees are taking up water, will improve our understanding of whether access to soil water influences rainforest tree productivity. This will also help in identifying complementary tree species to design mixed-species plantations that can make better use of water resources in the era of climate change.

4.3.5. Is the Assumption that Water-Stable Isotope Fractionation Does Not Occur During Water Uptake by Roots and Sap Transfer within the Tree Universally True?

In the context of hydrological changes, understanding the mechanisms of water uptake by trees, which play a critical role for entire ecosystems, may help to determine ecosystem responses to variations in water availability. One possible way to evaluate the spatiotemporal patterns of water uptake is to use natural tracers, such as oxygen and hydrogen isotopes. Many studies over the last two decades have used $\delta^{2} \mathrm{H}$ and $\delta^{18} \mathrm{O}$ to determine the proportions of different water sources used by forest tree species $[20,28,32,51]$. This is based on the assumption that $\delta^{2} \mathrm{H}$ and $\delta^{18} \mathrm{O}$ fractionation does not occur during water uptake by roots and sap transfer within the tree. However, there is evidence that isotope fractionations occur in halophyte, xerophyte, and some deciduous species [52,53], which then challenges the accuracy of tree water source identifications.

Apart from $\delta^{2} \mathrm{H}$ and $\delta^{18} \mathrm{O}$ fractionation, various factors can modify tree water uptake. Such factors include climate (e.g., season, water availability) [11,14,32], spatial variation [54,55], and species functional traits e.g., tree size [28]. Though there has been much research into the climate aspects of tree water source variation (e.g., [11,14,32]) and tree size (e.g., [28]), there has been no research into whether isotope fractionation of different species can be characterized by species functional traits, such as wood density, mean basal area increment, and successional status. Also, no study has yet been conducted on isotope fractionation at fine spatiotemporal resolutions across diverse climatic zones and Eco regions. 


\section{Concluding Remarks and Recommendations}

From this systematic literature review, it is clear there has been limited research into woody plant water sources across the globe. An increased study of woody plant water sources will help in identifying complementarities among tree species, which can then inform the design and management of mixed-species plantations. Even though we considered article until 2014, there are some researches [56-61] published after 2014. In most cases, those research themes matched with our proposed research themes. Addressing the research gaps identified in this paper will provide insights into the potential impacts of changing water regimes associated with global climate change. From the new research priorities described above, three broad recommendations are made:

1. There is a critical need to develop a single standard method to study plant water sources. This will lead to greater comparability of results from studies conducted across vegetation types and regions;

2. Catchment-scale hydrological models should consider plant water sources for better predictions of stream flows; and

3. Further research is required to better understand how plant water uptake strategies differ across vegetation types and climatic conditions, and how this understanding can be applied to the design of reforestation systems and understanding the likely impacts of climate change.

Supplementary Materials: The following are available online at http://www.mdpi.com/2306-5338/6/2/40/s1, Table S1: Species-specific information on plant functional traits and water sources.

Author Contributions: M.S.I.S. and J.H. designed the research idea. M.S.I.S. and M.A.S. searched for and extracted data. M.S.I.S. and M.A.S. analysed the data and prepared the results. M.S.I.S. wrote the article. J.H. and M.A.S. edited the manuscript.

Funding: The authors would like to thank The University of Queensland, Australia for funding this research.

Acknowledgments: The first author would like to thank Jack Baynes and John Medows for proofreading and English language editing.

Conflicts of Interest: The authors declare no conflict of interest.

\section{References}

1. Gazis, C.; Feng, X. A stable isotope study of soil water: Evidence for mixing and preferential flow paths. Geoderma 2004, 119, 97-111. [CrossRef]

2. Cui, Y.Q.; Ma, J.Y.; Sun, W.; Sun, J.H.; Duan, Z.H. A preliminary study of water use strategy of desert plants in Dunhuang, China. J. Arid Land 2015, 7, 73-81. [CrossRef]

3. Noy-Meir, I. Desert Ecosystems: Environment and Producers. Annu. Ecol. Syst. 1973, 4, 25-51. [CrossRef]

4. Webb, W.L.; Lauenroth, W.K.; Szarek, S.R.; Kinerson, R.S. Primary production and abiotic controls in forests, grasslands, and desert ecosystems of the United States. Ecology 1983, 64, 134-151. [CrossRef]

5. Saleska, S.R.; Didan, K.; Da Rocha, H.R.; Huete, A.R.; Huete, A.R.; Huete, A. Amazon Forests Green-Up During 2005 Drought. Science 2007, 318, 612. [CrossRef]

6. Anderson, L.O.; Malhi, Y.; Aragão, L.E.O.C.; Ladle, R.; Arai, E.; Barbier, N.; Phillips, O. Remote sensing detection of droughts in Amazonian forest canopies. New Phytol. 2010, 187, 733-750. [CrossRef] [PubMed]

7. IPCC. Climate Change 2013: The Physical Science Basis. In Contribution of Working Group I to the Fifth Assessment Report of the Intergovernmental Panel on Climate Change; Stocker, T., Qin, D., Plattner, G., Tignor, M., Allen, S., Boschung, J., Nauels, A., Xia, Y., Bex, V., Midgley, P., Eds.; Cambridge University Press: Cambridge, UK; New York, NY, USA, 2013.

8. Malhi, Y.; Aragao, L.E.O.C.; Galbraith, D.; Huntingford, C.; Fisher, R.; Zelazowski, P.; Sitch, S.; McSweeney, C.; Mei, P. Exploring the likelihood and mechanism of a climate-change-induced dieback of the Amazon rainforest. Proc. Natl. Acad. Sci. USA 2009, 106, 20610-20615. [CrossRef]

9. Sternberg, L.D.S.L.; Swart, P.K. Utilization of Freshwater and Ocean Water by Coastal Plants of Southern Florida. Ecology 1987, 68, 1898-1905. [CrossRef] [PubMed] 
10. James, M.L.; Zedler, J.B. Dynamics of Wetland and Upland Subshrubs at the Salt Marsh-Coastal Sage Scrub Ecotone. Am. Midl. Nat. 2000, 143, 298-311. [CrossRef]

11. Ehleringer, J.R.; Dawson, T.E. Water uptake by plants: Perspectives from stable isotope composition. Plantcell 1992, 15, 1073-1082. [CrossRef]

12. Gat, J.R. Oxygen and hydrogen isotopes in the hydrologic cycle. Annu. Earth Planet. Sci. 1996, 24, $225-262$. [CrossRef]

13. Sternberg, L.D.S.L.; Yakir, D. The use of stable isotopes to study ecosystem gas exchange. Oecologia 2000, 123, 297-311.

14. Dawson, T.E.; Mambelli, S.; Plamboeck, A.H.; Templer, P.H.; Tu, K.P. Stable isotopes in plant ecology. Ann. Rev. Ecol. Sys. 2002, 33, 507-559. [CrossRef]

15. Lin, G.; Sternberg, L.D.S.L. Hydrogen Isotopic Fractionation by Plant Roots during Water Uptake in Coastal Wetland Plants. In Stable Isotopes and Plant Carbon-water Relations; Elsevier BV: Amsterdam, The Netherlands, 1993; pp. 497-510.

16. Brunel, J.-P.; Kennett-Smith, A.K.; Walker, G.R. Field validation of isotopic procedures for determining sources of water used by plants in a semi-arid environment. J. Hydrol. 1995, 167, 351-368. [CrossRef]

17. Schwinning, S.; Starr, B.I.; Ehleringer, J.R. Dominant cold desert plants do not partition warm season precipitation by event size. Oecologia 2003, 136, 252-260. [CrossRef] [PubMed]

18. Querejeta, J.I.; Estrada-Medina, H.; Allen, M.F.; Jiménez-Osornio, J.J.; Ruenes, R. Utilization of bedrock water by Brosimum alicastrum trees growing on shallow soil atop limestone in a dry tropical climate. Plant Soil 2006, 287, 187-197. [CrossRef]

19. Querejeta, J.I.; Estrada-Medina, H.; Allen, M.F.; Jiménez-Osornio, J.J. Water source partitioning among trees growing on shallow karst soils in a seasonally dry tropical climate. Oecologia 2007, 152, 26-36. [CrossRef] [PubMed]

20. Asbjornsen, H.; Mora, G.; Helmers, M.J. Variation in water uptake dynamics among contrasting agricultural and native plant communities in the Midwestern U.S. Agric. Ecosyst. 2007, 121, 343-356. [CrossRef]

21. Hasselquist, N.J.; Allen, M.F.; Santiago, L.S. Water relations of evergreen and drought-deciduous trees along a seasonally dry tropical forest chronosequence. Oecologia 2010, 164, 881-890. [CrossRef]

22. Nie, Y.P.; Chen, H.S.; Wang, K.L.; Tan, W.; Deng, P.Y.; Yang, J. Seasonal water use patterns of woody species growing on the continuous dolostone outcrops and nearby thin soils in subtropical China. Plant Soil 2011, 341, 399-412. [CrossRef]

23. Jackson, P.C.; Bustamante, M.; Franco, A.; Caldas, L.; Igler, E.; Causin, F.; Meinzer, F.C.; Goldstein, G.; Rundel, P.W. Partitioning of soil water among tree species in a Brazilian Cerrado ecosystem. Tree Physiol. 1999, 19, 717-724. [CrossRef] [PubMed]

24. Prieto, I.; Armas, C.; Pugnaire, F.I. And Hydraulic lift promotes selective root foraging in nutrient-rich soil patches. Funct. Plant Boil. 2012, 39, 804. [CrossRef]

25. Ehleringer, J.R.; Phillips, S.L.; Schuster, W.S.F.; Sandquist, D.R. Differential utilization of summer rains by desert plants. Oecologia 1991, 88, 430-434. [CrossRef]

26. Fazey, I.; Fischer, J.; Lindenmayer, D.B. Who does all the research in conservation biology? Biodiv. Conser. 2005, 14, 917-934. [CrossRef]

27. Williams, D.G.; Ehleringer, J.R. Intra- and inter-specific variation for summer precipitation use in Pinyon-Juniper woodlands. Ecol. Monog. 2000, 70, 517-537.

28. Dawson, T.E.; Ehleringer, J.R. Streamside trees that do not use streamside water. Nature 1991, 350, $335-337$. [CrossRef]

29. Meinzer, F.; Goldstein, G.; Holbrook, N.M.; Cavelier, J.; Wright, S.J.; Andrade, J.L. Partitioning of soil water among canopy trees in a seasonally dry tropical forest. Oecologia 1999, 121, 293. [CrossRef] [PubMed]

30. Dawson, T.E. Fog in the California redwood forest: Ecosystem inputs and use by plants. Oecologia 1998, 117, 476-485. [CrossRef]

31. Mensforth, L.J.; Thorburn, P.J.; Tyerman, S.D.; Walker, G.R. Sources of water used by riparian Eucalyptus camaldulensis overlying highly saline groundwater. Oecologia 1994, 100, 21-28. [CrossRef]

32. Dawson, T.E.; Pate, J.S. Seasonal water uptake and movement in root systems of Australian phraeatophytic plants of dimorphic root morphology: A stable isotope investigation. Oecologia 1996, 107, 13-20. [CrossRef] 
33. Flanagan, L.B.; Ehleringer, J.R.; Marshall, J.D. Differential uptake of summer precipitation and groundwater among co-occurring trees and shrubs in the southwestern United States. Plant Cell Environ. 1992, 15, 831-836. [CrossRef]

34. Ehleringer, J.; Phillips, S. Ecophysiological factors contributing to the distributions of several Quercus species in the intermountain west. Ann. For. Sci. 1996, 53, 291-302. [CrossRef]

35. Burgess, S.S.; A Adams, M.; Turner, N.C.; Ward, B. Characterisation of hydrogen isotope profiles in an agroforestry system: Implications for tracing water sources of trees. Agric. Water Manag. 2000, 45, 229-241. [CrossRef]

36. Guojun, L.; Jinling, L.; Ximing, Z. Preliminary study of water sources for maintenance and water utilization strategies of Haloxylon ammodendron in the arid desert area of northwestern China. Peer. J. 2016. [CrossRef]

37. Engel, M.; Frentress, J.; Penna, D.; Andreoli, A.; Hecher, P.; van Meerveld, I.; Comiti, F. Ecohydrological dynamics of Alder trees in riparian zones: A tracer-based comparison study of two rivers in the Eastern Italian Alps. In Proceedings of the Workshop on Isotope-Based Studies of Water Partitioning and Plant-Soil Interactions in Forested and Agricultural Environments Villa Montepaldi, San Casciano in Val di Pesa, Florence, Italy, 27-29 September 2017.

38. Barbeta, A.; Mejía-Chang, M.; Ogaya, R.; Voltas, J.; Dawson, T.E.; Peñuelas, J. The combined effects of a long-term experimental drought and an extreme drought on the use of plant-water sources in a Mediterranean forest. Glob. Chang. Biol. 2015, 21, 1213-1225. [CrossRef]

39. Anderegg, W.R.L.; Kane, J.M.; Anderegg, L.D. Consequences of widespread tree mortality triggered by drought and temperature stress. Nat. Clim. Chang. 2013, 3, 30-36. [CrossRef]

40. Nepstad, D.C.; Tohver, I.M.; Ray, D.; Moutinho, P.; Cardinot, G. Mortality of large trees and lianas following experimental drought in an amazon forest. Ecology 2007, 88, 2259-2269. [CrossRef]

41. Bennett, A.C.; McDowell, N.G.; Allen, C.D.; Anderson-Teixeira, K.J. Larger trees suffer most during drought in forests worldwide. Nat. Plants 2015, 1, 15139. [CrossRef]

42. Lorimer, C.G.; Dahir, S.E.; Nordheim, E.V. Tree mortality rates and longevity in mature and old-growth hemlock-hardwood forests. J. Ecol. 2001, 89, 960-971. [CrossRef]

43. Van Mantgem, P.J.; Stephenson, N.L.; Byrne, J.C.; Daniels, L.D.; Franklin, J.F.; Fulé, P.Z.; E Harmon, M.; Larson, A.J.; Smith, J.M.; Taylor, A.H.; et al. Widespread Increase of Tree Mortality Rates in the Western United States. Science 2009, 323, 521-524. [CrossRef]

44. Peng, C.; Ma, Z.; Lei, X.; Zhu, Q.; Chen, H.; Wang, W.; Liu, S.; Li, W.; Fang, X.; Zhou, X. A drought-induced pervasive increase in tree mortality across Canada's boreal forests. Nat. Clim. Chang. 2011, 1, 467-471. [CrossRef]

45. Zhang, J.; Huang, S.; He, F. Half-century evidence from western Canada shows forest dynamics are primarily driven by competition followed by climate. Proc. Natl. Acad. Sci. USA 2015, 112, 4009-4014. [CrossRef] [PubMed]

46. Horton, J.L.; Hart, S.C. Hydraulic lift: A potentially important ecosystem process. Trends Ecol. Evol. 1998, 13, 232-235. [CrossRef]

47. Mueller, R.C.; Scudder, C.M.; Porter, M.E.; Trotter, R.T.; Gehring, C.A.; Whitham, T.G. Differential tree mortality in response to severe drought: Evidence for long-term vegetation shifts. J. Ecol. 2005, 93, 1085-1093. [CrossRef]

48. Anderson-Teixeira, K.J.; McGarvey, J.C.; Muller-Landau, H.C.; Park, J.Y.; Gonzalez-Akre, E.B.; Herrmann, V.; Bennett, A.C.; So, C.V.; Bourg, N.; Thompson, J.R.; et al. Size-related scaling of tree form and function in a mixed-age forest. Funct. Ecol. 2015, 29, 1587-1602. [CrossRef]

49. Romero-Saltos, H.; Sternberg, L.D.S.L.; Moreira, M.Z.; Nepstad, D.C.; Sternberg, L.D.S.L. Rainfall exclusion in an eastern Amazonian forest alters soil water movement and depth of water uptake. Am. J. Bot. 2005, 92, 443-455. [CrossRef]

50. Meißner, M.; Kohler, M.; Schwendenmann, L.; Holscher, D. Partitioning of soil water among canopy trees during a soil desiccation period in a temperate mixed forest. Biogeoscience 2012, 9, 3465-3474. [CrossRef]

51. Brooks, R.; Barnard, R.; Coulombe, R.; McDonnell, J.J. Ecohydrologic separation of water between trees and streams in a Mediterranean climate. Nat. Geosci. 2010, 3, 100-104. [CrossRef]

52. Ellsworth, P.Z.; Williams, D.G. Hydrogen isotope fractionation during water uptake by woody xerophytes. Plant Soil 2007, 291, 93-107. [CrossRef] 
53. Zhao, L.; Wang, L.; Cernusak, L.A.; Liu, X.; Xiao, H.; Zhou, M.; Zhang, S. Significant difference in hydrogen isotope composition between xylem and tissue water in Populus euphratica. Plant Cell Environ. 2016, 39, 1848-1857. [CrossRef]

54. McPherson, G.R.; Weltzin, J.F. Spatial and temporal soil moisture resource partitioning by trees and grasses in a temperate savanna, Arizona, USA. Oecologia 1997, 112, 156-164.

55. Stratton, L.C.; Meinzer, F.; Goldstein, G. Temporal and spatial partitioning of water resources among eight woody species in a Hawaiian dry forest. Oecologia 2000, 124, 309-317. [CrossRef] [PubMed]

56. Del Castillo, J.; Comas, C.; Voltas, J.; Ferrio, J.P. Dynamics of competition over water in a mixed oak-pine Mediterranean forest: Spatio-temporal and physiological components. Forest Ecol. Mang. 2016, 382, 214-224. [CrossRef]

57. Evaristo, J.; McDonnell, J.J.; Clemens, J. Plant source water apportionment using stable isotopes: A comparison of simple linear, two-compartment mixing model approaches. Hydrol. Proc. 2017, 31, 3750-3758. [CrossRef]

58. Geris, J.; Tetzlaff, D.; McDonnell, J.; Anderson, J.; Paton, G.; Soulsby, C. Ecohydrological separation in wet, low energy northern environments? A preliminary assessment using different soil water extraction techniques. Hydrol. Proc. 2015, 29, 5139-5152. [CrossRef]

59. Gómez, P.M.; Aguilera, M.; Pemán, J.; Pelegrín, E.G.; Ferrio, P.J. Uncoupling between soil and xylem water isotopic composition: how to discriminate mobile and tightly-bound water? Geophy. Res. Abs. 2014, 16, EGU2014-1340.

60. Martín-Gómez, P.; Serrano, L.; Ferrio, J.P. Short-term dynamics of evaporative enrichment of xylem water in woody stems: implications for ecohydrology. Tree Phy. 2016. [CrossRef]

61. Sohel, M.S.I. Spatial and Temporal Variation of Sources of Water Across Multiple Tropical Rainforest Trees. Ph.D. Thesis, The University of Queensland, Queensland, Australia, 2018.

(C) 2019 by the authors. Licensee MDPI, Basel, Switzerland. This article is an open access article distributed under the terms and conditions of the Creative Commons Attribution (CC BY) license (http://creativecommons.org/licenses/by/4.0/). 